\title{
General Education Policy in Minority Schools in Georgia
}

\author{
Giorgi Momtselidze*
}

Received: May 1, 2020; received in revised form: October 9, 2020; accepted: October 12, 2020

\begin{abstract}
:
Introduction: The historical conditions that have developed over the centuries, as well as the migration processes of the 19th and 20th centuries, have determined the multi-ethnic composition of the country's population. Georgia, as a post-Soviet country, has been transitioning from totalitarianism to democracy for the last few years. The country is in the process of developing into an open, civil society; the modern concept of human-free development, the new principles and values of a civil society and the priorities of public consent placed the problem of ensuring the creation of tolerance in the foreground. Therefore, it is important to define the place and role of national minorities in modern social life.

The aim of the article is to determine the problems of non-Georgian general education schools in the educational space of Georgia and develop the necessary recommendations for the solution of these problems.

The object of the study is non-Georgian-language public schools in the territory of Georgia, where the teaching and learning processes of the representatives of national minorities is underway.

Purpose: The study will discuss the current situation in non-Georgian language general education schools. We will present the recommendations that we think will have a positive impact on the development of nonGeorgian language educational institutions in the current education reform.

Methods: The article examines the situation in the state regarding the issue of general education of national minorities, international experiences, problems and the means of solving them. Through surveys, in-depth interviews, focus group, data collection, organisation, analysis and synthesis, attention was paid to three problematic issues. These were as follows: 1. low motivation of the students in non-Georgian language schools; 2. low level of knowledge of the state language among the students; 3. textbook availability in non-Georgian language schools of Georgia.
\end{abstract}

Conclusion: A content analysis was used to draw common conclusions. From the in-depth study of the materials, specific recommendations have been made regarding the effectiveness. The policies that were

\footnotetext{
* Giorgi Momtselidze, Grigol Robakidze University, Scientific Research Laboratory of Juvenology, Tbilisi, Georgia; g.momtselidze@gruni.edu.ge
} 


\title{
Acta Educationis Generalis \\ Volume 10, 2020, Issue 3
}

\begin{abstract}
implemented in relation to the national goals of general education in national minorities are less result-oriented and need to be improved.
\end{abstract}

Key words: national minorities, non-Georgian language schools, education policy.

\section{Introduction}

PIRLS/ePIRLS and PISA 2015 International Studies on the Academic Achievements of Ethnic Minorities. The analysis clearly shows that the average achievement of non-Georgian-speaking students in literacy is significantly lower than in Georgian-speaking students (Academic Achievements of Ethnic Minorities in International Assessments).

The data recorded on the school's graduation exams (computer adaptive testing) is also noteworthy, as the results of the 12th graders of non-Georgian language schools over the years were drastically lower than the results of the 12th graders of the Georgian language schools (Office of the Minister of State for Tolerance and Civil Integration of Georgia, 2014).

Based on the above, the research question was formulated as follows: what factors determine the low results of students in non-Georgian language schools compared to Georgian schools?

To research the causes, we held meetings with the target groups, where the directors and teachers of Tbilisi, Ninotsminda, Dmanisi, Gardabani and nonGeorgian language schools were presented. Surveys were also conducted using a questionnaire and in-depth interviews. The following three main factors were identified as a result of the data analysis:

1. Low motivation of students $-15 \%$.

2. Low level of knowledge of the state language (both in teachers and students) $-37 \%$.

3. Existing textbooks $-48 \%$.

\section{Low motivation of students in non-Georgian language schools of Georgia}

In terms of student motivation, it is important to note that not only are the minority members poorly informed about the ongoing processes in Georgia but also the majority of the Georgian population is unaware of the problems, history, culture, achievements and other characteristics of ethnic minorities. The lack of accurate information prevents the formation of an objective opinion towards the representatives of minorities. Because of this, unhealthy stereotypes replace objective information, which is also a deterrent for integration and the protection of human rights. This problem is enhanced by the fact that the school textbooks poorly reflect the traditions and other characteristics of ethnic minorities living in Georgia, which contributes to the alienation between the majority and the 


\section{Acta Educationis Generalis \\ Volume 10, 2020, Issue 3}

minority. Representatives of ethnic minorities are often excluded from ongoing processes in the country. This is especially true for the minorities living in Samtskhe-Javakheti and Kvemo Kartli, who, among other problems, suffer from a lack of information about the ongoing processes in the country in a language that they can understand. Furthermore, there are a lack of special state programs that promote and encourage the employment of minorities in the central and regional governmental authorities. Ignorance of the state language is one of the main obstacles that prevents minority members from fully participating in state life. This is directly related to the protection of the rights of ethnic minorities. The work done in this direction does not have a significant impact nowadays, which is also a problem that must be solved by the state. All these internal or external factors lower the students' motivation, which in turn, affects their academic performance and literacy.

\section{Low level of knowledge of the state language among students and teachers in non-Georgian language schools of Georgia}

Due to complex factors, minority students in non-Georgian language schools have not been given the opportunity to study the state language to the extent that it would be sufficient for them to fully integrate into society. In 1997, the government approved a state programme for the study of the Georgian language in Kvemo Kartli and Samtskhe-Javakheti, or in regions where non-Georgian populations predominate. The developers of the programme said that the shortage of qualified Georgian language teachers in these regions is a particularly important obstacle to improving the quality of Georgian language teaching. Within the framework of the programme, the Georgian language, history and geography teachers took training courses. In non-Georgian language schools, the Georgian language teachers were given a salary supplement in the form of a grant to motivate them. Within the framework of the programme, teachers from other regions of Georgia were mostly sent from Rustavi and Tbilisi to minority regions. In 2004, in parallel with this programme, a competition for the selection of teachers of Georgian language, as well as history and geography in Georgian, was announced. Although they offered larger grants than before, the goal was the same, as follows: to create financial incentives for qualified teachers to move from other parts of Georgia to ethnic minority regions. Currently, several of these teachers teach Georgian language and literature, history and geography in Georgian in non-Georgian language schools. The new programme, "Teach and Learn in Georgia", which was created by the Ministry of Education, Science, Sports and Culture of Georgia, is noteworthy. It should be noted that most of the programme teachers do not speak the language in which the learning process takes place. This issue greatly complicates their perfect communication. 


\section{Acta Educationis Generalis \\ Volume 10, 2020, Issue 3}

The UNESCO Interim Strategy (2002-2007) reads the following: "Education has become truly accessible, especially for those who have not previously been able to do so (the poor, women, rural population, minorities, refugees, people affected by natural disasters, people with special needs."

Although not all problems in Georgia have been finally solved in terms of access to education, a number of measures have been taken to make primary, secondary and higher education equally accessible to all, regardless of social, ethnic, religious, linguistic or worldview backgrounds. Article 13 of the Law of Georgia on General Education defines "neutrality and anti-discrimination" in general education schools, where we read the following: "The school is obliged to protect and promote the culture of tolerance and mutual respect between students, parents and teachers, regardless of their social, ethnic, religious, linguistic and worldview affiliation" (Article 13, paragraph 6); "On the basis of equality, the school protects the individual and collective rights of minority members to freely use their mother tongue, maintain or express their cultural identity." (Law of Georgia on General Education, 2005, Article 13, paragraph 7) International Acts on Minority Education states that minorities not only have the right to maintain their identity through their mother tongue but also the right to integrate and participate in a wider national society through the study of the state language. Therefore, the diversity of representatives of national minorities in OSCE countries can be considered one of the most effective means of achieving the goals of international acts in the field of protection and integration of national minorities. Recommendations for primary and secondary education were created to provide the right path for the states in the field of education and implementation of educational policies and relevant programmes in the language of national minorities. The proposed approach is based on the results of research in the field of education and is a realistic interpretation of the relevant international norms.

Any assimilationist approach that teaches the curriculum only in the state language, and in which minority children are fully integrated into the majority children's class, contradicts international norms. This applies equally to isolated schools, where the entire educational programme is taught only in the native language of the minority during the entire educational process, and the language of the majority is either not taught at all or is taught only at the minimum level.

Over the years, the style of formulating minority rights in international norms has evolved. Passive formulas, such as "... individuals belonging to national minorities cannot be denied the right ...", as defined in the International Covenant on Civil and Political Rights (OSCE, 1996) was replaced with more positive, pro-active approaches, such as "... States will protect the ethnic, cultural, linguistic and religious identity of national minorities ...", according to a Copenhagen meeting document on the human dimension (OSCE, 1990). Therefore, it is important for the state to make more efforts to increase the 


\section{Acta Educationis Generalis \\ Volume 10, 2020, Issue 3}

competence of the state language proficiency level, first among teachers, and then among students.

\section{Textbooks available in non-Georgian language schools of Georgia}

This factor, which most respondents $(48 \%)$ focused on, is the topic of textbooks. In the non-Georgian language schools, the main textbooks in grades I-VI are bilingual, and in grades VII-XII, they are mainly in native (Russian, Armenian, Azerbaijani) languages. That is one of the most challenging issues regarding minority education in Georgia (Tabatadze, 2017). In the process of studying this issue, using the case-study method, non-Georgian language textbooks were developed together with the subject departments of the schools. The analysis of the material revealed the following types of problems:

- Non-Georgian language schools, unlike Georgian language schools, do not have the freedom of choice of textbooks.

- In the bilingual textbooks, the text is divided into Georgian and non-Georgian parts according to the paragraphs, which creates a number of difficulties for the student. In particular, if $\mathrm{s} / \mathrm{he}$ does not know both languages thoroughly, $\mathrm{s} /$ he will not be able to combine the text and will study only a part of the text written in a language $\mathrm{s} / \mathrm{he}$ understands. Therefore, the student will not be able to connect or complete the text and therefore, they will develop high thinking skills.

- During the lesson, the teacher has to translate an unknown part of the text to the student. As a result of this, the teaching time lacks certain activities. Unlike Georgian-language schools, less time is left for the second and third phases of the lesson, which is important for the development of high thinking skills.

- Qualified bilingual specialists remain a problem in non-Georgian language schools. Mostly, the lessons (despite the bilingualism of the textbooks in grades I-VI) are monolingual.

- Dictionaries of terms are almost non-existent in bilingual textbooks, which is one of the most important issues for students to be able to understand the material to be studied in both languages.

- All textbooks in grades VII-XII are monolingual. We find textbooks that are only in Georgian (for example, VII-XII grades of music and art textbooks).

- Programme incompatibility for students of VII-XII grades with the material of the relevant class of Georgian language school (for example: ninth grade mathematics textbooks).

- Part of the assignments in English language textbooks are only in Georgian, which hinders the student's ability to learn independently.

- The issue of textbooks is more acute in science subjects. Physics textbooks are defined for trimester teaching (which is no longer available in schools), 


\section{Acta Educationis Generalis \\ Volume 10, 2020, Issue 3}

except in grades XI and XII (physics is no longer taught programmatically in Grade XII, although the textbook exists). The textbooks are not bilingual.

- Chemistry textbooks are old editions (2008-2010). The subject of chemistry in Georgian language schools starts in the eighth grade, and in the ninth grade, in a non-Georgian language. In the ninth grade, the teacher is forced to use three textbooks because the offered ninth grade book is a direct translation of the textbook of the Georgian school.

- The seventh grade biology textbook is also intended for trimester teaching. The ninth grade textbook does not exist at all. Schools use the eighth grade textbook for Georgian schools.

- Some problems arise when studying their native language and literature. Artificial barriers to state and patriotic upbringing are being created. These textbooks have been published in neighbouring countries and are ideologically represented. This issue poses a certain threat to the national goals of general education.

It is noteworthy to consider the number of non-Georgian language schools in Georgia and their sustainability over the years. An analysis of statistical data for 2007 and 2013 shows that the number of non-Georgian language schools in dynamics has sharply decreased.

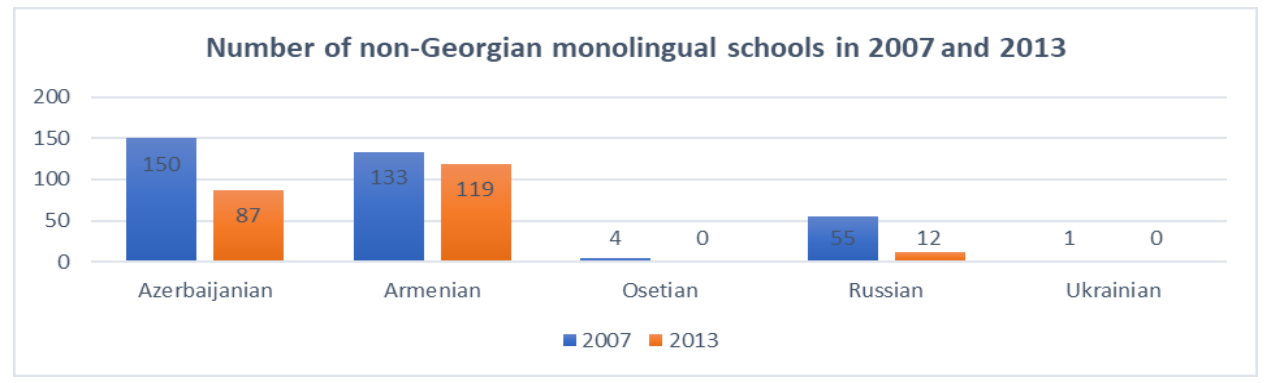

Figure 1. Number of non-Georgian monolingual schools in 2007 and 2013.

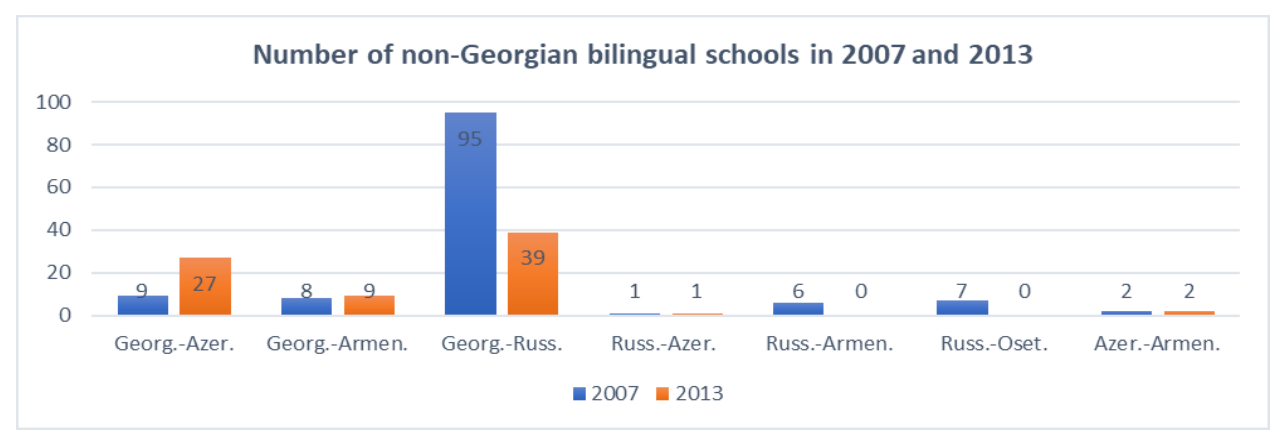

Figure 2. Number of non-Georgian bilingual schools in 2007 and 2013. 


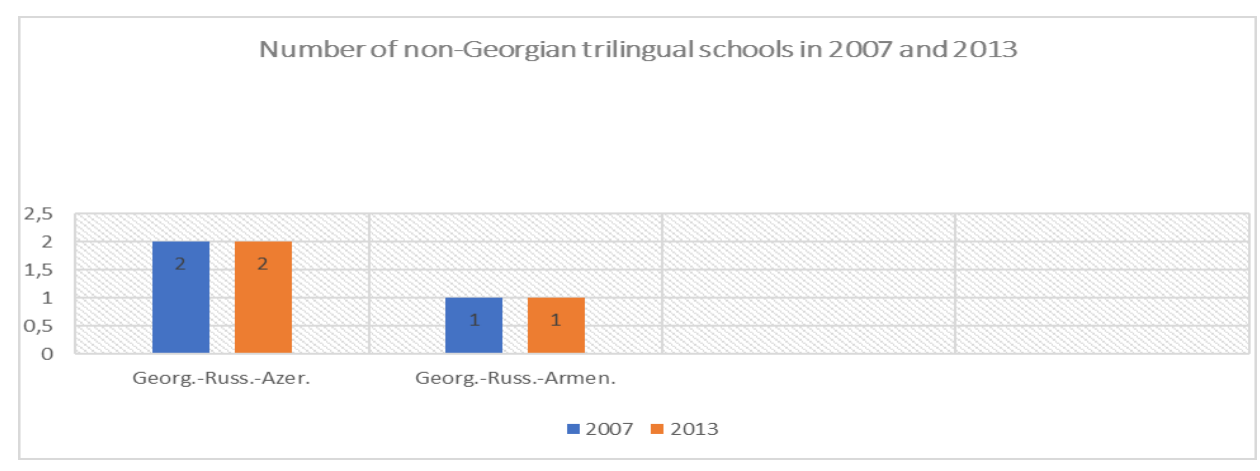

Figure 3. Number of non-Georgian trilingual schools in 2007 and 2013.

Some members of ethnic minorities have expressed great confidence in Georgian schools, and they are enrolling their children in the first grade (mostly the Azerbaijani-speaking population in the Kvemo Kartli region). However, Georgian schools were not prepared to meet this challenge. A first-grader who speaks only his native language, does not speak Georgian and is enrolled in a Georgian school will struggle to communicate with his teachers (it makes sense that Georgian school teachers do not speak their native language) and classmates. It is easy to imagine how many problems will be associated with the development of high thinking skills in a class where $40 \%-45 \%$ of students do not speak the state language.

The National Concept of Tolerance and Civic Integration and the Evaluation Document for the Implementation of the 2009-2014 Action Plan discuss final school exams, which are no longer valid in Georgia since 2018.

According to the results of the 2012 final exams, here is the number of students admitted to the subjects - students of non-Georgian language schools of compact settlements (Akhalkalaki, Ninotsminda, Marneuli, Bolnisi, Dmanisi, Aspindza).

Table 1

The number of students admitted to the subjects - students of non-Georgian language schools of compact settlements

\begin{tabular}{lcccc}
\hline Subject & $\begin{array}{c}\text { Number of } \\
\text { exam takers }\end{array}$ & Passed & $\begin{array}{c}\text { Could not } \\
\text { pass }\end{array}$ & $\begin{array}{c}\text { \% of failed } \\
\text { students }\end{array}$ \\
\hline Georgian & 2262 & 1936 & 326 & 14.41202476 \\
Maths & 2288 & 1711 & 577 & 25.21853147 \\
Foreign Language & 2328 & 2101 & 227 & 9.750859107 \\
History & 2210 & 1987 & 223 & 10.09049774 \\
\hline
\end{tabular}




\begin{tabular}{lllll}
\hline Geography & 2222 & 2039 & 183 & 8.235823582 \\
Biology & 2227 & 1896 & 331 & 14.86304445 \\
Chemistry & 2237 & 1994 & 243 & 10.86276263 \\
Physics & 2290 & 1604 & 686 & 29.95633188 \\
\hline
\end{tabular}

According to the results of the 2012 final exams, here is the number of students who passed the exams across Georgia.

Table 2

The number of students who passed the exams

\begin{tabular}{lcccc}
\hline Subject & $\begin{array}{c}\text { Number of } \\
\text { exam takers }\end{array}$ & Passed & Could not pass & $\begin{array}{c}\text { \% of failed } \\
\text { students }\end{array}$ \\
\hline Georgian & 39444 & 38691 & 753 & 1.909035595 \\
Maths & 39621 & 38457 & 1164 & 2.937835996 \\
Foreign Language & 39625 & 38169 & 1456 & 3.67444795 \\
History & 38931 & 38304 & 627 & 1.610541728 \\
Geography & 38814 & 38000 & 814 & 2.097181429 \\
Biology & 38766 & 37727 & 1039 & 2.680183666 \\
Chemistry & 38817 & 38221 & 596 & 1.535409743 \\
Physics & 38981 & 37208 & 1773 & 4.548369719 \\
\hline
\end{tabular}

A large number of students in non-Georgian language schools in 2011 did not exceed the minimum threshold. Of the 4,110 students, only 2,500 students were able to meet the requirements for the final exams. Regarding the statistical analysis that was presented in 2012, there is a big difference between the indicators of non-Georgian and Georgian language school students. The percentage of the students who failed the exams and who graduated from nonGeorgian language schools varies from $8.23 \%$ to $29.95 \%$ in various subjects. The same rate ranges from $1.53 \%$ to $4.54 \%$ across Georgia. Therefore, we can conclude that the quality of teaching in non-Georgian language schools is much lower than in Georgian language schools. This factor explains the international research of PIRLS/ePIRLS and PISA 2015, as well as why we have results that speak about the academic achievements of ethnic minorities and why the average achievement of students in literacy results in non-Georgian language schools is significantly lower than in Georgian students. 


\section{Acta Educationis Generalis \\ Volume 10, 2020, Issue 3}

\section{Conclusion}

In conclusion, although there is a clear record in the 2018 National Curriculum " 1 . In schools where students from national minorities study, the development of book speech in the state language is a priority, one of the tools of which is bilingual education. Bilingual education involves the use of two languages in the teaching-learning process, which forms the basis of bilingual literacy. 2. When introducing the bilingual education model, the school should give the adolescent the opportunity to master the native language in the native language according to his/her age. The educational content of each subsequent stage of the introduction of bilingual education should be based on and develop the knowledge and skills acquired at the previous stage" (National Curriculum Article 2011-2016), the issue of textbooks is still one of the main challenges in non-Georgian language schools. Currently, the Ministry of Education, Science, Sports and Culture of Georgia is actively working on a solution, and in the 2019-2020 academic year, new bilingual textbooks will be included in grades I-VI in non-Georgian language schools. The circumstances to be considered are as follows: raising the language competence of teachers in the state language; texts, rather than paragraphs dropped from contexts, with content translations; dictionaries of terminology should appear in bilingual textbooks; paragraphs of ideological content of other countries should be reviewed in the native language and literature and removed at the level of the school's policy.

It is also important to define the policy of certification of native language teachers in non-Georgian language schools. To date, these teachers have not been fully involved in the teacher's career advancement scheme, nor have they been able to receive a salary supplement. Russian language teachers (who teach in Russian language schools) who obtained the certificate after passing the exam in 2011-2012, have not yet been recognised by the state, and the exam for Armenian and Azerbaijani language teachers cannot be held today. This issue dramatically violates the rights of native language teachers in non-Georgian language schools. To regulate this issue, it is important to coordinate the work of legal entities of public law within the Ministry of Education, Science, Sports and Culture of Georgia. Additionally, over the years, despite the efforts of the National Curriculum Department of the Georgian and non-Georgian schools, the problem remains of the issue of compatibility of the software, the OSCE (1990) recommended for minority rights, the pro-active approach or acting in accordance with the Copenhagen Document, Article 31, which calls on them to take special measures to ensure the full equality of members of national minorities. To this end, it is important to create specific working groups that will be staffed with policymakers, industry experts and subject matter experts.

For the coordinated solution of the problems outlined in the article, I believe that it is important to create an ethnic minorities policy office in the Ministry of the Education, Science, Sports and Culture. This would ensure the development of a policy and the implementation of various government agencies, international 


\section{Acta Educationis Generalis \\ Volume 10, 2020, Issue 3}

organisations, NGOs obo sector and the public defender's office. Its area should be not only general education but also in pre-school, higher education, culture and sports. The service should ensure compliance with the recommendations issued by the various agencies. For example, judging by the examples discussed in this article, the Ministry of Education, Science, Sports and Culture of Georgia has not yet been able to implement recommendations, such as the OSCE's Recommendations on Minority Rights, Article 31 of the Copenhagen Document, "Tolerance and National Integration Strategy and Action Plan for 2009-2014 performance assessment document", prepared by the Georgian State Minister's office on tolerance and civic integration, the Report of the Public Defender of Georgia (2018), human rights and freedoms situation and several recommendations prepared by the Non-Governmental Organization Civil Integration and Inter-Ethnic Relations Centre (2014).

This is a small list, and it is important to consider it in the shortest possible time, as the problems will be duplicated during the policy-making process.

\section{References}

Academic Achievements of Ethnic Minorities in International Assessments (PIRLS, ePIRLS and PISA). Retrieved from https://naec.ge/\#/ge/post/1759

Center for Civil Integration and Inter-Ethnic Relations. (2014). A study of the effectiveness of general education voucher funding in the context of equality. Tbilisi. Retrieved from https://www.cciir.ge/images/pdf/ vaucheri.pdf

Center for Civil Integration and Inter-Ethnic Relations (2011). Issues of State Language Teaching; Problems and Challenges. Tbilisi.

Law of Georgia on General Education. Article N13.

National Curriculum Article 2011-2016, 8-1. Linguistic education in nonGeorgian language schools/sectors.

Office of the Minister of State for Tolerance and Civic Integration of Georgia. (2014). National Document for Evaluation of Tolerance and Civil Integration and Evaluation of the Implementation of the Action Plan for 2009-2014.

OSCE. (1990). Copenhagen Meeting Documents on the Human Dimension. Retrieved from https://www.osce.org/odihr/elections/14304

OSCE. (1996). The Hague Recommendations on the Education Rights of National Minorities. Explanatory Note. Retrieved from https://www.osce.org/hcnm/hague-recommendations

Report of the Public Defender of Georgia on the Situation of Human Rights and Freedoms in Georgia (2018).

Tabatadze, Sh. (2017). Minority Education in Georgia: Is It Delivering What is Expected? Diaspora, Indigenous, and Minority Education, 11(1), 17-30, https://doi.org/10.1080/15595692.2016.1245658

UNESCO Intermediate Strategy (2002-2007). 